\title{
The Application Of The Model System The Achievement Of The Concept As An Attempt To Overcome The Misconceptions Language Indonesia
}

\author{
Annim Hasibuan ${ }^{1)}$, Ridho Kurniawan ${ }^{2)}$ \\ 1) Fakultas Keguruan dan Ilmu Pendidikan, Universitas Islam Labuhan Batu, Rantauprapat \\ 2) Fakultas Keguruan dan Ilmu Pendidikan, Universitas Alwasliyah Rantauprapat
}

\author{
*Coresponding Author \\ Email : annimhasibuan@gmail.com
}

\begin{abstract}
This research was conducted in class X MA Subulussalam Sumberjo. District Torgamba, Kabupaten Labuhanbatu Selatan. Object in this research is : the Application of the model system the achievement of the concept as an attempt to overcome the misconceptions of Indonesian Language, the Subject of the research is MA Subulussalam Sumberjo. The average value of student learning outcomes before the applied method of the System the achievement of concept is at 36,83\% with the criteria is very low. Means the average value of the Indonesian Language students should be improved in the next cycle by applying the method of System achievement concept. The average value of learning outcomes of Indonesian students after applied System method is the achievement of the concept in the first cycle of 64,58\% with the criteria of being and in classical $63 \%$. means the value obtained by the students have not yet reached the kertuntasan classical amounting to > 85\%. The average value of learning outcomes of Indonesian students after applied System method is the achievement of the concept in the second cycle of $72,42 \%$ with very high criteria and in classical $88 \%$. mean value learning outcomes the student has attained mastery in the classical. The increase in the average value of learning outcomes of Indonesian students from before action to the cycle of 27,75\%, and from cycle I to cycle II by $7.83 \%$. In cycle I, the average results of observation of the learning activities of students by 2,81 (70,24\%) with good category, and in cycle II the average results of observation of the learning activities of students by 3,57 (89,29\%) with very good category. In cycle I, the average observation of teacher activity is 3,83 with good category, and in cycle II the average results of the observation of teacher activity by 3.75 with a very good category
\end{abstract}

Keywords: Achievement Of The Concept, Misconceptions

\section{INTRODUCTION}

Language Indonesia has a two position is very important, namely: 1) As the Language of National, and 2) As the Language of the Country. In his capacity as the national language, Indonesian language serves as: a) the Symbol of the pride of nationality, b) a Symbol of national identity, c) Tool liaison between residents, interregional and intercultural, and d) a Tool that allows the unification of the various ethnic groups with socio-cultural background and different languages into one unified national round. While in his capacity as a state language, Indonesian language serves as: a) the official Language of the state, b) the Language of instruction in the education world, c) a means of transportation on a national level for the benefit of the planning and implementation of development, and d) a Tool for the development of culture, science and technology.

The position of Indonesian language as the language of the Country one of which serves as the language of instruction in education. Based on this then the Indonesian language 
is used as the language of instruction in institutions of education from Early childhood Education (PAUD, Elementary School (SD), junior high School (SMP), Upper Secondary school (SMA) and all institutions of higher education in Indonesia. For it is precisely the need and importance of Indonesian language learning in all institutions of education in Indonesia. Why Indonesian language learning is important in educational institutions? In general, the language has a central role in the development of the intellectual, social, and emotional learners. Language is the success of the students in the study of all fields of study. Language learning is expected to help learners get to know him, the culture, and the cultures of other people. In addition, language learners are expected to be able to express ideas and feelings, participate in the community who use such language, and to find and use analytical skills and imaginative that was in him. For that Indonesian language learning get an important role for education in Indonesia because it is the official language in all fields. Learning Indonesian is directed to enhance the ability of learners to communicate in the Indonesian language is good and right. The communication was expected to occur both orally and in writing. More than that, the understanding of the language of Indonesia is expected to foster the appreciation of the learners on the results of the work of literature of the nation of Indonesia.

Indonesian Language subjects into the basic capital for the learning and development of children in Indonesia. Indonesian Language subjects nurture and develop the self-confidence of students as communicators, imaginative thinkers and citizens of the state of Indonesia which literat or information literate. Indonesian Language learning aims to foster and develop knowledge and communication skills required of learners in education and in the world of work. The development of the curriculum, including lessons in Indonesian Language is a logical consequence of the development of life and the development of knowledge about language and how language is manifest in the theory of language learning up to date. The development of the theory of language learning contribute to the understanding of the nature of language, the nature of how humans learn and the nature of communication inter-cultural, and also about the interest of the man himself that all of these are interrelated and affect one another. Understanding it is intended to increase the quality of Indonesian Language learning on an ongoing basis. To develop the potential of learners is necessary to do research related to applying the models of learning achievement of concept, the model of the achievement of the concept is expected to overcome the misconceptions Indonesian students.

\section{RESEARCH METHODS}

\section{Type Of Research}

In accordance with the type of problem, the research is more appropriate to use a classroom action research (PTK). Class action research (PTK) in English is a Classroom Action research $(\mathrm{CAR})$ is a research activity carried out in the classroom.

According to Suharsimi Arikunto, Suhardjono, and Supardi (2008) Action Research (PTK) is :

1. Research refers to an activity of observing an object by using the ways and the rules of a particular methodology to obtain the data or information useful in improving the quality of a thing that attract the interest and important for researchers.

2. Action refers to a motion activities, which are deliberately made with a specific purpose. In the research-shaped series of cycle activities for students.

Classroom action research is a scrutiny of the activities of learning in the form of an act, which deliberately raised and occurs in a class together. Such actions are given by the teacher or by the direction of teachers conducted by the students. 
More Suharsimi Arikunto, Suhardjono, and Supardi explain :

"In the PTK, the position of researchers is equivalent to the teacher, in the sense that each has a role and responsibility that need each other and complement each other to achieve the goal. The role of cooperation (collaboration) to determine the success of PTK especially on the activities of diagnosing the problem, formulate a proposal, carry out research (carry out the action, observation, data recording, evaluation, and reflection), analyze the data and should held seminar results, and preparing the final report." This study has the stages of the research cycle. According to Suharsimi Arikunto (2008), namely : "there are 4 important stages in the action research, namely (1) planning, (2) implementation, (3) observation, (4) reflection"

\section{Data Collection Techniques}

Data collection techniques in this research is :

1. Test

A test given to students at the end of the action phase, precisely after the administration of the act by the researcher. The results obtained are used to (1) determine which students are having difficulty, namely that students low ability in doing the test, (2) determine the layout of the difficulty of the students in doing the test, which indirectly into students ' difficulty in understanding the subject matter, (3) determine whether the learning outcomes of students has increased, as seen from the mastery learning students.

2. Interview

The interview was conducted at the planning stage. Interviews were conducted to master the field of study of mathematics and to the students who become the subject of research. Interview to teachers was conducted to determine the difficulties commonly experienced by students in understanding the material. While the interview to the students in the focus right to the student who has a very low ability to know the layout of the difficulty of the students in understanding the material.

3. Observation

Observations made at the stage of observation. Observation was conducted on all students when learning activity takes place, precisely at the time of the action by the researchers. Observation was conducted to determine how the activities and skills students when learning takes place.

\section{Analyze test results}

To know or see the students ' ability in understanding the system of linear equations two variables, it can be seen from the results of student learning. The level of mastery or absorbance students will look at the high and low raw scores achieved.

According to Uzer Usman (2007), there are criteria of mastery learning of individuals and the classical :

1) absorption of the individual/individual

A student called a complete study when it has reached a score of $65 \%$ or 6.5 . In determining the absorption of the students individually/individual used the following formula :

Where PDS $=$ Percentage of Absorption

Criteria $\quad: 0 \%<$ PDS $<75 \%$ has not been completed

$: 75 \%<$ PDS $100 \%$ has been completed

2) Absorption Classical

A class is said to have completed the study if the class there is $85 \%$, which has reached the absorption of $>75 \%$, mastery is calculated by the formula : 
$\mathrm{D}=\frac{X}{N} \times 100 \%$

Description :

$\mathrm{D}=$ the Percentage of the class of which have been thoroughly studied

$\mathrm{X}=$ the Number of students who have been thoroughly studied

$\mathrm{N}=$ the Number of all students

In this study, the target to be achieved is the percentage of classical completeness achieve > $85 \%$. if the target is achieved, then the research was successful and no need to be continued to the next cycle, and vice versa if the target is not achieved, then the research is continued to the next cycle.

\section{Before Action}

\section{RESULTS AND DISCUSSION}

Based on the researchers observations on the course of learning before done action is supported with the instrument, namely the observation sheet and test of learning outcomes that are given to students, seen from the observation sheet of teacher and observation of the students, there are two things that can be analyzed, namely from the internal and external factors. Internal factors, namely low interest and understanding of students in learning Indonesian Language cause the results to learn Indonesian students low.

External factors namely :

1. The teacher has not been able to use time efficiently and not yet able to manage the class effectively.

2. The strategy used less support in learning the Indonesian Language so that raises the low interest of students in learning the Indonesian Language.

\section{After The Action}

Cycle I

Based on the researchers ' observations on the course of learning after done action is supported with the instrument, namely the observation sheet and test of learning outcomes that are given to students, seen from the observation sheet of teacher and observation of the students are already showing an increase on the activity of the students that was originally not used to learn the group now began to love learning group and have already started to get used to implement the method of learning system is the achievement of the concept.

But there are still some things that become problems that :

1. Of the factors the researchers themselves; researchers still do not effectively manage the classroom and researchers are still not able to allocate time appropriately.

2. Of the factors students; students are not fully consistent in carrying out the method of the system achievement concept.

From the results of student learning overall in cycle I, the researcher is sufficient maximum in applying the understanding of the concept of students with percentage calculation of the average in the classical style was $63 \%$ in the good category and observations made on the activity of students percentage calculation of the average is 2,833 with good category. 
Based on the results of student learning is obtained before action occurs an increase 236,83\% to $64,58 \%$ in cycle I. and it can be concluded that there is increase in the percentage of students ability, which occurred before the given action of the first cycle and after the action of the first cycle of $27,75 \%$ and absorption of classical before the action amounted to $13 \%$ and after the action of the first cycle of $63 \%$, an increase of $50 \%$, these results indicate that the application of the method of system the achievement of the concept applied by the researchers can be understood by the students. But these results are not in accordance with the specified target that mastery in the classical $(>85 \%)$. So it can be concluded that in classical learning ability of the students is not in accordance with the set target.

\section{Cycle II}

The results of the observation on the activities of teachers or researchers and students in the second cycle shows that the implementation of the system method is the achievement of concept in this study work well and effectively. So the problems that occur in cycle I have been able to diatasin well.

After administration of the action in the second cycle by applying the method of system the achievement of the concept, the obtained average ability level in the first cycle of $64,58 \%$ and in cycle II amounted to $72,42 \%$, can be seen an increase from cycle I to cycle II sebaesar 7,83 $\%$. And complete absorption of the classical style of the first cycle by $63 \%$ and in cycle II amounted to $88 \%$ so it can be seen an increase from cycle I to cycle II sebaesar $25 \%$ so it can be concluded that in the classical ability level of the students already corresponds to a target that has been determined so that it is not necessary to do the cycle III.

Based on this study obtained the results of the study Indonesian students by using the method of system the achievement of the concept of improving learning outcomes. It can be concluded approach to the understanding of the concept can be overcome student misconceptions.

\section{CONCLUSION}

Based on the results and discussion of research, conclusions can be drawn as follows :

1. The average value of student learning outcomes before the applied method of the System the achievement of concept is at $36,83 \%$ with the criteria is very low. Means the average value of the Indonesian Language students should be improved in the next cycle by applying the method of System achievement concept.

2. The average value of learning outcomes of Indonesian students after applied System method is the achievement of the concept in the first cycle of $64,58 \%$ with the criteria of being and in classical $63 \%$. means the value obtained by the students have not yet reached the kertuntasan classical amounting to $>85 \%$.

3. The average value of learning outcomes of Indonesian students after applied System method is the achievement of the concept in the second cycle of $72,42 \%$ with very high criteria and in classical $88 \%$. mean value learning outcomes the student has attained mastery in the classical.

4. The increase in the average value of learning outcomes of Indonesian students from before action to the cycle of $27,75 \%$, and from cycle I to cycle II by $7.83 \%$. 


\section{REFERENCES}

Arikunto, S, (2006) PenelitianTindakanKelas, BumiAksara, Jakarta.

Arikunto, S, Suhardjono \& Supardi. (2013). Penelitian Tindakan Kelas. Jakarta : Bumi Aksara

Purwanto, M. Ngalim. (2010). Psikologi Pendidikan. Depdikbud : Jakarta.

Sabandar, (2009), Psikologi Pendidikan, PT. Bima Aksara : Malang.

Sujono, (2002), Model - Model Pembelajaran, Jakarta: Depdikbud

Uzer Usman, 2008, Strategi Pembelajaran, Jakarta : Erlangga 